\title{
ADRENERGIC MODULATION OF MELANOMA CELLS PROLIFERATION
}

\author{
MIHAELA SURCEL ${ }^{1,2}$, CONSTANTIN CĂRUNTU $^{3,4} *{ }^{3}$ MIRCEA TAMPA $^{5}$, CLARA MATEI $^{5}$, \\ SILVIU PIȚURU ${ }^{5}$, SIMONA-ROXANA GEORGESCU ${ }^{5}$, CAROLINA CONSTANTIN ${ }^{1,7}$, SABINA \\ ZURAC $^{6,7}$, MONICA NEAGU $^{1,2,7}$ \\ ${ }^{1}$ Immunology Department, "Victor Babes" National Institute of Pathology, Bucharest, Romania \\ ${ }^{2}$ Faculty of Biology, University of Bucharest, Bucharest, Romania \\ ${ }^{3}$ Department of Physiology, "Carol Davila" University of Medicine and Pharmacy, Bucharest, Romania \\ ${ }^{4}$ Department of Dermatology, "Prof. N. C. Paulescu” National Institute of Diabetes, Nutrition and Metabolic Diseases, Bucharest, \\ Romania \\ ${ }^{5}$ Department of Dermatology, "Carol Davila" University of Medicine and Pharmacy, Bucharest, Romania \\ ${ }^{6}$ Department of Pathology, Faculty of Dental Medicine, "Carol Davila" University of Medicine and Pharmacy, Bucharest, \\ Romania \\ ${ }^{7}$ Colentina Clinical Hospital, Bucharest, Romania
}

*corresponding author: costin.caruntu@gmail.com

Manuscript received: March 2018

\begin{abstract}
Investigation of the complex cellular and molecular mechanisms underlying cutaneous melanoma development is of major interest in biomedical research. Within our study we have developed an in vitro experimental system using A375 human melanoma cell line to investigate the impact of adrenergic modulation in melanoma. Thus, we have studied the proliferative effect of norepinephrine and epinephrine in the absence and presence of several specific inhibitors. We have found that the pro-proliferative action of norepinephrine and epinephrine can be overridden by certain inhibitors. Moreover, for some of the inhibitors, membrane integrity hindering is associated with the actual decrease in the proliferative capacity of the tumoral cells. Our study continues a series of experimental data that shows neurotransmitters to be involved in the proliferation of melanoma cells and opens new research pathways for further therapeutic approaches in this field.
\end{abstract}

\section{Rezumat}

Investigarea mecanismelor complexe moleculare și celulare care stau la baza tumorigenezei în melanomul cutanat prezintă un interes major în cercetarea biomedicală. În studiul nostru a fost dezvoltat un sistem experimental in vitro utilizând linia celulară de melanom uman A375 pentru investigarea efectului modulării adrenergice în melanom. A fost studiat efectul indus asupra capacității proliferative a celulelor tumorale de către adrenalină și noradrenalină în absența și prezența unor inhibitori specifici. Am observat că acțiunea pro-proliferativă a adrenalinei și noradrenalinei poate fi contracarată de o serie de inhibitori. Afectarea integritătii membranei celulare este asociată cu scăderea capacității proliferative a celulelor tumorale în cazul unora dintre inhibitorii studiați. Studiul nostru continuă o serie de date experimentale obținute care prezintă implicarea neurotransmițătorilor în proliferarea celulelor de melanom şi deschide astfel noi domenii de cercetare pentru identificarea unor noi metodologii terapeutice.

Keywords: melanoma, proliferation, adrenergic, catecholamines, epinephrine, norepinephrine, propranolol, phentolamine, yohimbine

\section{Introduction}

Melanoma is one of the most aggressive forms of human cancer, being responsible for the vast majority of skin cancer deaths and its incidence is continuously rising worldwide. [1-4] Investigation of the complex cellular and molecular mechanisms underlying melanoma development is of major interest in biomedical research and could lead to the identification of new potential therapeutic targets [2-8].

Neuroendocrine factors play an important role in diverse physiological and pathophysiological processes in the skin [9-16] and various studies suggest their involvement in melanoma formation and progression [17-19].

The impact of adrenergic modulation in melanoma was recently brought into attention by different research groups. Both alpha- and beta-adrenoceptors have shown to be expressed in melanoma tissue samples and in different human melanoma cell lines [20-23]. However, adrenergic receptor expression and melanoma cell response to adrenergic stimulation depends on both the receptor and the cell type [24]. Several studies have shown that catecholamines induce melanoma progression and stimulate melanoma cell proliferation by activation of beta-adrenergic receptors. 
FARMACIA, 2018, Vol. 66, 5

$[22,23,25]$. Other research reported a significant inhibition of cell growth and motility induced by incubation of different human melanoma cell lines with a beta 2 adrenergic receptor agonist [26]. Moreover, alpha1-adrenergic stimulation was shown to decrease proliferation and to increase tyrosinase activity of human melanoma cells [21].

In a previous research performed on murine melanoma cell lines we have shown that exposure to high concentrations of epinephrine and norepinephrine induces an important increase in cell proliferation [19]. In the present study we expand our research on A375 human melanoma cell line, investigating the impact of adrenergic stimulation on cell proliferation using specific activators and inhibitors.

\section{Materials and Methods}

Cell line. A375 cell line (ECACC collection, cell culture supplied by Sigma under the purchase code $88113005)$ is a human melanoma standard cell line derived from an amelanotic melanoma tumour. According to the producer, cells were cultivated at $3 \times 10^{4}$ cells $/ \mathrm{cm}^{2}$ in DMEM medium supplemented with $2 \mathrm{mM}$ glutamine and $15 \%$ foetal calf serum (FCS), and kept in $5 \% \mathrm{CO}_{2}$ at $37^{\circ} \mathrm{C}$. When $70 \%-80 \%$ cell confluency was reached after 3 days of cultivation a 1:5 splitting was applied using $0.25 \%$ trypsin/ EDTA. For the experimental systems 96 wells culture plates were used and 3000 cells/well were seeded $24 \mathrm{~h}$ prior to applying the tested compounds. Lactate dehydrogenase (LDH) test used CytoTox 96 Non-Radioactive Cytotoxicity Assay kit (Promega Corporation) to assess membrane integrity upon A375 cell line cultivation in various concentrations of the tested compounds. After $24 \mathrm{~h}$ of cultivation in compounds, from the cultures, supernatants were harvested and tested accordingly. Briefly, the enzyme release due to the damaged membranes was measured as optical density (OD) at $492 \mathrm{~nm}$ owing to the conversion of tetrazolium salts to red formazan. According to the kit, the formazan quantity is directly proportional with the LDH released in the cultivation medium by the damaged cells. All samples were investigated in triplicate and the experiments were reproduced for three times. The results are presented as mean value $\mathrm{OD} \pm \mathrm{SD}$.
Cell proliferation was assessed using standard MTS assay (CellTiter 96AQueous One Solution Cell Proliferation kit; Promega Corporation). Cell cultures after $24 \mathrm{~h}$ of incubation with the compounds were subjected to the test according to the producer and the reduction of tetrazolium compound [3-(4,5-dimethylthiazol-2-yl)-5-(3-carboxymethoxyphenyl)- 2(4-sulfophenyl)-2H-tetrazolium, inner salt; MTS] to formazan was registered at $492 \mathrm{~nm}$. The quantified OD is directly proportional with the number of proliferating cells. The OD for each sample was recorded with a spectral scanning multimode reader (Varioskan ${ }^{\circledR}$ Flash, Thermo Scientific). All samples were investigated in triplicate and the experiments were reproduced for three times. The results are presented as mean value $\mathrm{OD} \pm \mathrm{SD}$.

Neurotransmitters and specific inhibitors. We have tested various concentrations of epinephrine (E) and norepinephrine (NE) purchased from Sigma, on the A375 cell line proliferation capacity. Specific inhibitors yohimbine (Y), propranolol (Pro) and phentolamine $(\mathrm{Ph})$ were purchased from Sigma and used in concentrations prior established [27-29].

\section{Results and Discussion}

In our previous published data [19] we have established the concentration domain of stress molecules such epinephrine (E) and norepinephrine (NE) that can influence melanoma cells proliferation. Thus, we have tested these concentration domains on human melanoma cells, namely we have investigated the influence in the $1 \mu \mathrm{M}-10 \mathrm{nM}$ range for NE, $5 \mu \mathrm{M}$ $50 \mathrm{nM}$ for $\mathrm{E}$; cellular systems were investigated in the presence and absence of specific inhibitors $\mathrm{Y}$, Pro and $\mathrm{Ph}$ at fixed concentrations $10 \mu \mathrm{M}, 200 \mu \mathrm{M}$ and $1 \mu \mathrm{M}$ respectively. After $24 \mathrm{~h}$ of incubation in NE or E with/without inhibitors, various cellular effects were obtained. Membrane integrity evaluated as LDH release induced by NE is strictly dose-dependent and when introducing concomitantly the specific inhibitor, we registered the same strict dose-dependency (Figure 1a). When investigating the proliferative capacity we registered an increase in the proliferation only at $100 \mathrm{nM}$, effect that is down-regulated by its specific inhibitor (Figure 1b). 


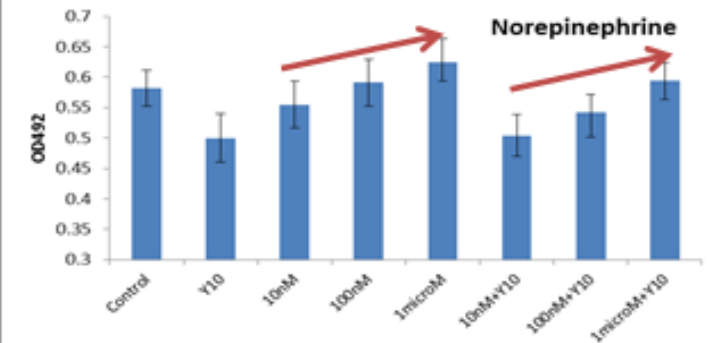

a

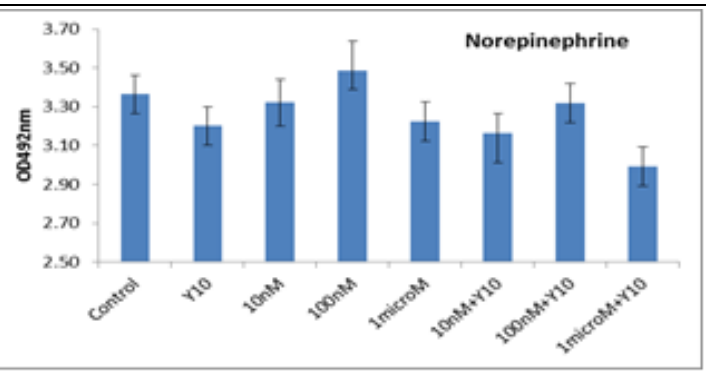

b

Figure 1.

A375 cell line after $24 \mathrm{~h}$ cultivation in NE with/without specific inhibitor Y; a) LDH release; b) Cell proliferation MTS assay. Absolute OD $492 \mathrm{~nm}$ for triplicates from 3 experiments (mean $\mathrm{OD} \pm \mathrm{SD}$ ); red arrow depicting the dose-dependency

Investigating the effect of $\mathrm{E}$ on the melanoma cell proliferation we have registered a LDH release in a dose-dependent mode like in the case of NE, but when applying the specific inhibitor we did not register the same dose-dependency; thus, the effect is more a plateau that shows a statistically significant reduction of cellular viability at $75 \%$ compared to controls and the same values when comparing $\mathrm{Y}$ alone (Figure 2a). The proliferative capacity of A375 cell line is decreased in a perfect dose dependent manner (Figure 2b). The inhibition inflicted by $\mathrm{Y}$ is statistically significant at higher $\mathrm{E}$ concentrations $(500 \mathrm{nM})$, while not significant at lower concentrations.

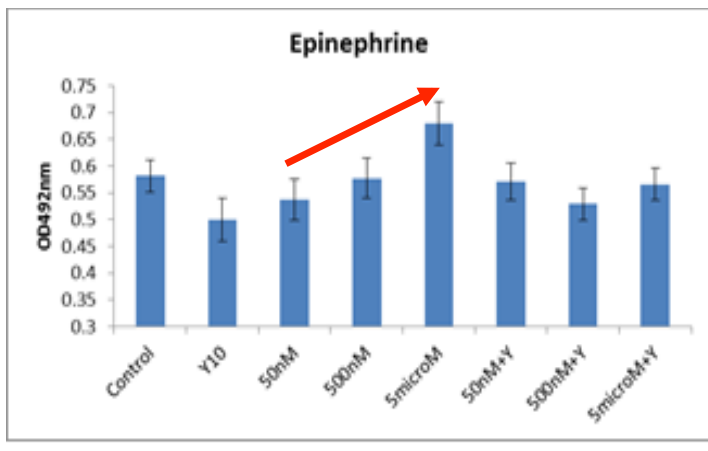

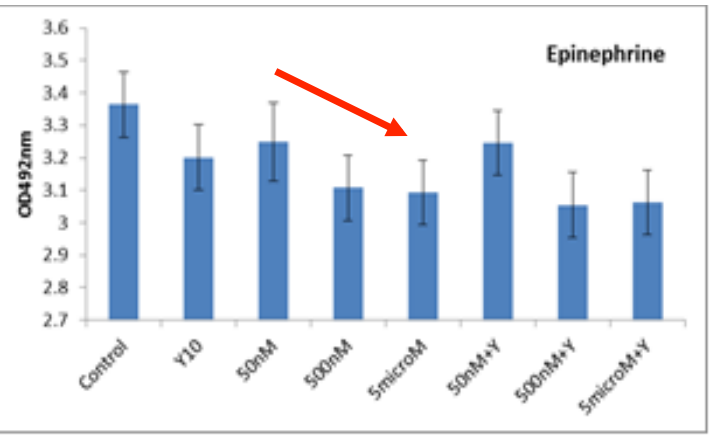

b

Figure 2.

A375 cell line after $24 \mathrm{~h}$ cultivation in E with/without specific inhibitor Y; a) LDH release; b) Cell proliferation MTS assay. Absolute OD $492 \mathrm{~nm}$ for triplicates from 3 experiments (mean OD \pm SD); red arrow depicting the dose-dependency

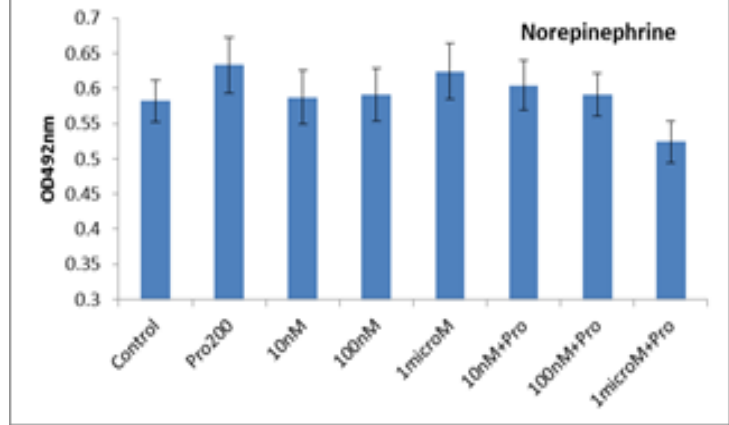

a

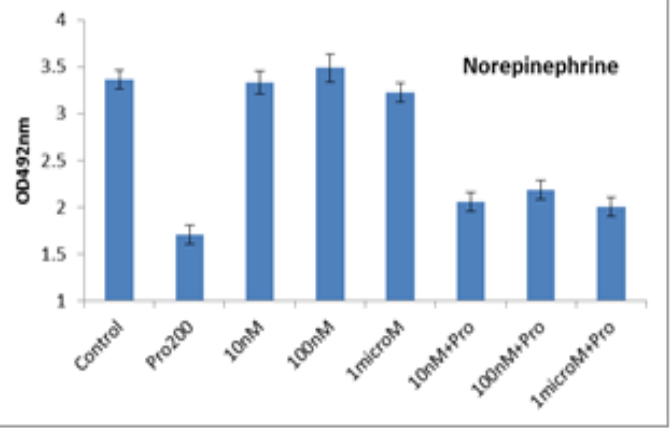

b

Figure 3.

A375 cell line after 24 h cultivation in NE with/without specific inhibitor Pro; a) LDH release; b) Cell proliferation - MTS assay. Absolute OD $492 \mathrm{~nm}$ for triplicates from 3 experiments (mean OD \pm SD)

We have observed an interesting case, when A375 cell line was cultivated in the presence of NE with/ without inhibitor Pro (Figure 3); LDH release was not statistically influenced by the inhibitor (Figure 3a) and we noticed only a statistically significant decrease of $\mathrm{LDH}$ release when $\mathrm{NE}$ at $1 \mu \mathrm{M}$ was simultaneously 
incubated with Pro. Although LDH release was not registered as statistically significant in this system, the proliferation capacity of cells was found statistically reduced at 50\% no matter the applied NE concentration (Figure 3b). We can point out that, in this case, not the hindering of cell membrane integrity has triggered the decreased proliferative capacity, but other intracellular signalling mechanisms developed by Pro at this concentration.

When applying inhibitor Pro with E (Figure 4) we registered a complete different cellular behaviour.
Thus, at higher E concentrations $(5 \mu \mathrm{M})$ in the presence of Pro there was an increase of LDH release (Figure 4a) matching the decrease in the cellular proliferation, but not in a dose-dependent manner (Figure 4b).

Testing the cell line in the presence of NE and inhibitor Ph (Figure 5) has revealed that LDH release at $1 \mu \mathrm{M} \mathrm{Ph}$ is identical with the release registered in the combination with NE $1 \mu \mathrm{M}$ (Figure 5a). The proliferative capacity (Figure 5b), correlated perfectly with the LDH release, namely at the concentrations where $\mathrm{LDH}$ release is high, the proliferation rate is low.

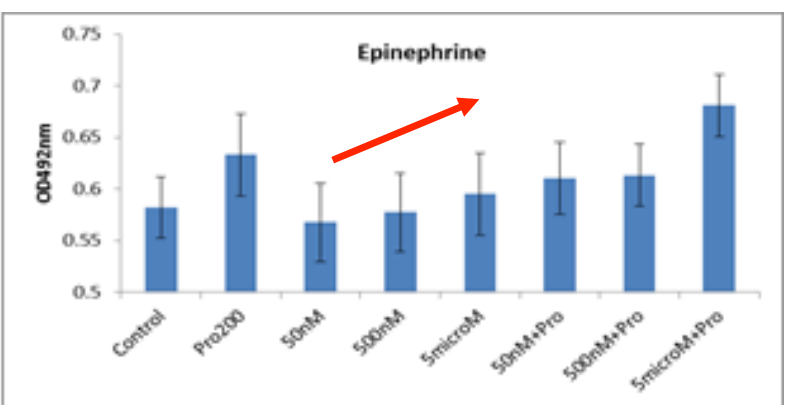

a

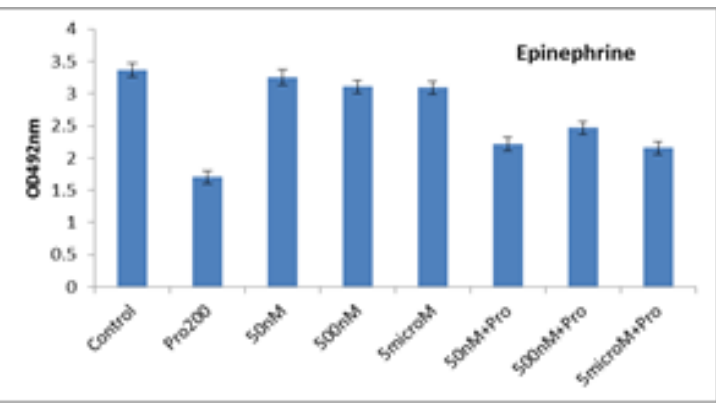

b

Figure 4.

A375 cell line after 24 h cultivation in E with/without specific inhibitor Pro; a) LDH release; b) Cell proliferation MTS assay. Absolute OD $492 \mathrm{~nm}$ for triplicates from 3 experiments (mean OD \pm SD); red arrow depicting the dose-dependency

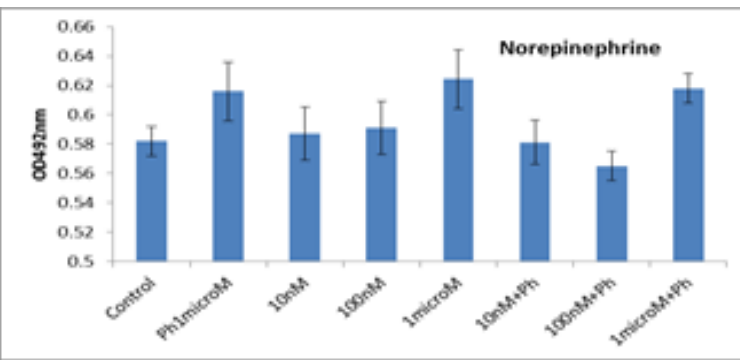

a

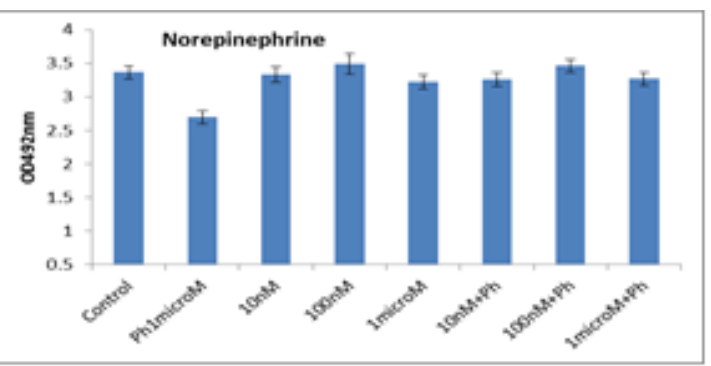

b

Figure 5.

A375 cell line after 24 h cultivation in NE with/without inhibitor Ph; a) LDH release; b) Cell proliferation - MTS assay. Absolute OD $492 \mathrm{~nm}$ for triplicates from 3 experiments (mean OD \pm SD)

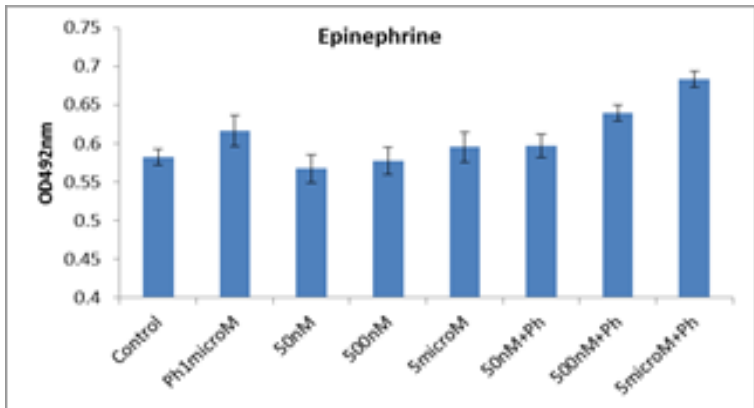

a

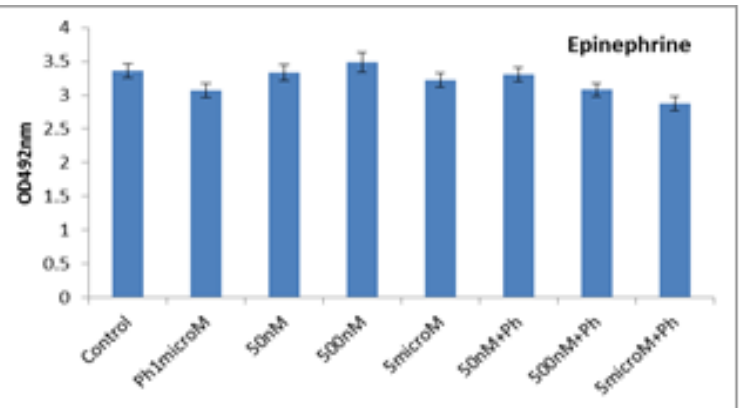

$\mathrm{b}$

Figure 6.

A375 cell line after $24 \mathrm{~h}$ cultivation in $\mathrm{E}$ with/without inhibitor $\mathrm{Ph}$; a) LDH release; b) Cell proliferation - MTS assay. Absolute OD $492 \mathrm{~nm}$ for triplicates from 3 experiments (mean OD $\pm \mathrm{SD}$ ) 
The A375 cell line is quite insensitive to the combined action of $\mathrm{E}$ with $\mathrm{Ph}$ for both $\mathrm{LDH}$ release (Figure 6a) and proliferative capacity (Figure $6 \mathrm{~b}$ ). Thus we have registered an increase of the LDH release statistically significant only in the combination of high dose epinephrine and $\mathrm{Ph}$, combined with the decrease in the proliferation capacity at exactly the same combination. For the rest of concentrations and combinations we did not register statistically different actions.

\section{Conclusions}

We can conclude that in the framework of the in vitro experimental systems developed using A375 human melanoma cell line the proliferative action developed by the tested epinephrine and norepinephrine can be overridden by some of the inhibitors, this effect being correlated on both membrane integrity and actual proliferative capacity. Our study continues a series of experimental data that shows neurotransmitters to be involved in the proliferation of melanoma cells.

\section{Acknowledgement}

The study was financed through the grant PN-III-P11.2-PCCDI-2017-0341 (PATHDERM). The presented study will be integrated in the original part of the $\mathrm{PhD}$ thesis of the first author, Mihaela Surcel.

\section{References}

1. Nikolaou V, Stratigos AJ, Emerging trends in the epidemiology of melanoma. Br J Dermatol., 2014; 170(1): 11-19.

2. Neagu M, Constantin C, Zurac S, Immune parameters in the prognosis and therapy monitoring of cutaneous melanoma patients: experience, role, and limitations. Biomed Res Int., 2013; 2013: 1-13.

3. Neagu M, Constantin C, Tanase C, Immune-related biomarkers for diagnosis/prognosis and therapy monitoring of cutaneous melanoma. Expert Rev Mol Diagn., 2010; 10(7): 897-919.

4. Neagu M, Constantin C, Manda G, Margaritescu I, Biomarkers of metastatic melanoma. Biomark Med., 2009; 3(1): 71-89.

5. Palmieri G, Ombra M, Colombino M, Casula M, Sini M, Manca A, Paliogiannis P, Ascierto PA, Cossu A, Multiple molecular pathways in melanomagenesis: characterization of therapeutic targets. Front Oncol., 2015; 5: 1-16.

6. Surcel M, Constantin C, Caruntu C, Zurac S, Neagu $\mathrm{M}$, Inflammatory cytokine pattern is sex-dependent in mouse cutaneous melanoma experimental model. $J$ Immunol Res., 2017; 2017: 1-10.

7. Zurac S, Neagu M, Constantin C, Cioplea M, Nedelcu R, Bastian A, Popp C, Nichita L, Andrei R, Tebeica T, Tanase C, Chitu V, Caruntu C, Ghita M, Popescu C, Boda D, Mastalier B, Maru N, Daha C, Andreescu B, Marinescu I, Rebosapca A, Staniceanu F, Negroiu G, Ion DA, Nikitovic D, Tzanakakis GN, Spandidos DA, Tsatsakis AM, Variations in the expression of TIMP1, TIMP2 and TIMP3 in cutaneous melanoma with regression and their possible function as prognostic predictors. Oncol Lett., 2016; 11(5): 3354-3360.

8. Sevastre B, Sárpataki O, Stan RL, Taulescu M, Sevastre-Berghian AC, Olah NK Furtuna F, Hanganu D, Hangan AC, Cenariu M, Bâldea IA, Anticancer activity of Euonymus europaeus fruits extract on human melanoma cells. Farmacia, 2017; 65(1): 56-62.

9. Roosterman D, Goerge T, Schneider SW, Bunnett NW, Steinhoff M, Neuronal control of skin function: the skin as a neuroimmunoendocrine organ. Physiol Rev., 2006; 86(4): 1309-1379.

10. Lupu M, Caruntu A, Caruntu C, Papagheorghe LML, Ilie MA, Voiculescu V, Boda D, Constantin C, Tanase C, Sifaki M, Drakoulis N, Mamoulakis C, Tzanakakis G, Neagu M, Spandidos DA, Izotov BN, Tsatsakis $\mathrm{AM}$, Neuroendocrine factors: The missing link in non melanoma skin cancer (Review). Oncol Rep., 2017; 38(3): 1327-1340.

11. Georgescu SR, Sârbu MI, Matei C, Ilie MA, Caruntu C, Constantin C, Neagu M, Tampa M, Capsaicin: Friend or foe in skin cancer and other related malignancies?. Nutrients, 2017; 9(12): 1-14.

12. Filippi A, Caruntu C, Gheorghe RO, Deftu A, Amuzescu B, Ristoiu V, Catecholamines reduce transient receptor potential vanilloid type 1 desensitization in cultured dorsal root ganglia neurons. J Physiol Pharmacol., 2016; 67(6): 843-850.

13. Ginghină $\mathrm{O}$, Negrei C, Hudiță A, Ioana-Lavric V, Gălățeanu B, Dragomir S, Burcea Dragomiroiu GTA, Bârcă M, Niţipir C, Diaconu CC, Pantea Stoian AM, Iordache N, Bălănescu A. In vitro impact of some natural compounds on HT-29 colorectal adenocarcinoma cells. Farmacia, 2017; 65(6): 947-953.

14. Căruntu C, Boda D, Musat S, Căruntu A, Poenaru E, Calenic B, Savulescu-Fiedler I, Draghia A, Rotaru M, Badarau AI, Stress effects on cutaneous nociceptive nerve fibers and their neurons of origin in rats. Rom Biotehnol Letters, 2014; 19(4): 9525-9538.

15. Căruntu C, Grigore C, Căruntu A, Diaconeasa A, Boda $\mathrm{D}$, The role of stress in skin diseases. Internal Medicine-Medicina Internă, 2011; 8(3): 73-84.

16. Căruntu C, Ghiţă MA, Căruntu A, Boda D, The role of stress in the multifactorial etiopathogenesis of acne. Ro Med J., 2011; 58(2): 98-101.

17. Colucci R, Moretti S, The role of stress and betaadrenergic system in melanoma: current knowledge and possible therapeutic options. J Cancer Res Clin Oncol., 2016; 142(5): 1021-1029.

18. Caruntu C, Mirica A, Rosca AE, Mirica R, Caruntu A, Tampa M, Matei C, Constantin C, Neagu M, Badarau AI, Badiu C, Moraru L, The role of estrogens and estrogen receptors in melanoma development and progression. Acta Endocrinologica (Buc), 2016; 12(2): 234-241.

19. Caruntu C, Boda D, Constantin C, Caruntu A, Neagu $\mathrm{M}$, Catecholamines increase in vitro proliferation of murine B16F10 melanoma cells. Acta Endocrinologica (Buc), 2014; 10(4): 545-558.

20. Scarparo AC, Visconti MA, de Oliveira AR, Castrucci $\mathrm{AM}$, Adrenoceptors in normal and malignant human melanocytes. Arch Dermatol Res., 2000; 292(5): $265-$ 267.

21. Scarparo AC, Sumida DH, Patrão MT, Avellar MC, Visconti MA, Maria de Lauro Castrucci A, Catecholamine 
effects on human melanoma cells evoked by alpha1adrenoceptors. Arch Dermatol Res., 2004; 296(3): 112-119.

22. Yang EV, Kim SJ, Donovan EL, Chen M, Gross AC, Webster Marketon JI, Barsky SH, Glaser R, Norepinephrine upregulates VEGF, IL-8, and IL-6 expression in human melanoma tumor cell lines: implications for stressrelated enhancement of tumor progression. Brain Behav Immun., 2009; 23(2): 267-275.

23. Moretti S, Massi D, Farini V, Baroni G, Parri M, Innocenti $\mathrm{S}$, Cecchi $\mathrm{R}$, Chiarugi $\mathrm{P}, \beta$-adrenoceptors are upregulated in human melanoma and their activation releases pro-tumorigenic cytokines and metalloproteases in melanoma cell lines. Lab Invest., 2013; 93(3): 279-290.

24. Janik ME, Szlęzak D, Surman M, Gołas A, Lityńska A, Przybyło M, Diversified $\beta$-2-adrenergic receptor expression and action in melanoma cells. Anticancer Res., 2017; 37(6): 3025-3033.

25. Sereni F, Dal Monte M, Filippi L, Bagnoli P, Role of host $\beta 1$ - and $\beta 2$-adrenergic receptors in a murine model of B16 melanoma: functional involvement of $\beta 3$ adrenergic receptors. Naunyn Schmiedebergs Arch Pharmacol., 2015; 388(12): 1317-1331.
26. Wnorowski A, Sadowska M, Paul RK, Singh NS, Boguszewska-Czubara A, Jimenez L, Abdelmohsen K, Toll L, Jozwiak K, Bernier M, Wainer IW, Activation of $\beta 2$-adrenergic receptor by $\left(R, R^{\prime}\right)-4$ '-methoxy-1naphthylfenoterol inhibits proliferation and motility of melanoma cells. Cell Signal., 2015; 27(5): 997-1007.

27. Valles SL, Benlloch M, Rodriguez ML, Mena S, Pellicer JA, Asensi M, Obrador E, Estrela JM, Stress hormones promote growth of B16-F10 melanoma metastases: an interleukin 6- and glutathione-dependent mechanism. J Transl Med., 2013; 11: 1-14.

28. Fuller BB, Drake MA, Spaulding DT, Chaudhry F, Downregulation of tyrosinase activity in human melanocyte cell cultures by yohimbine. $J$ Invest Dermatol., 2000; 114(2): 268-276.

29. Pan L, Liu C, Kong Y, Piao Z, Cheng B, Phentolamine inhibits angiogenesis in vitro: Suppression of proliferation migration and differentiation of human endothelial cells. Clin Hemorheol Microcirc., 2017; 65(1): 31-41.

30. Sârbu MI, Tampa M, Mitran MI, Mitran CI, Limbău AM, Georgescu SR, Adverse reactions of biological therapies in patients with psoriasis. Journal of Mind and Medical Sciences, 2017; 4(1): 1-10. 